DOI: 10.5800/GT-2021-12-1-0511

\title{
DEFORMATION AND STRUCTURAL EVOLUTION OF METAMORPHIC COMPLEXES OF THE TALDYK ANTIFORM IN THE EAST MUGODZHAR ZONE OF URALS (WEST KAZAKHSTAN)
}

\author{
B.G. Golionko ${ }^{\bowtie}$, A.V. Ryazantsev
}

Geological Institute, Russian Academy of Sciences, 7 Pyzhevsky Ln, Moscow 119017, Russia

ABSTRACT. The study is focused on mesostructural folded parageneses of the Taldyk antiform (a.k.a. Taldyk block) located in the East Mugodzhar zone. The sequence of their formation is established; the structural evolution of the study area is investigated, and four stages of deformation are identified. The NW-trending folds $\mathrm{F}_{1}$ with SE-vergence formed during the first stage of deformation, DI. The geodynamics and timeline of this stage remain unclear. The W-E-trending folds F2 with E-vergence are related to tectonic movements that took place at stage DII. In the western limb of the antiform, stage DII is evidenced by folds overturned towards the south-east. In the eastern limb, folds plunge to the east and northeast. These fold structures are probably related to the Devonian subduction-obduction processes. At stage DIII, thrusting of the Taldyk antiform over the West Mugodzhar zone and folding F3 with W-vergence is related to the Ural continental collision in the Late Paleozoic, which completed the geodynamic evolution of the Ural paleo-ocean. At stage DIV, postcollisional shearing is evidenced by folds F4 with steeply dipping hinges, which completed the structural evolution of the study area.

KEYWORDS: Taldyk antiform; East Mugodzhar zone; East Ural megazone; metamorphic complex; collision; structural evolution; stage of deformation; asymmetric fold; vergence; hinge; axial plane

FUNDING: The study was carried out under the state assignment of the Geological Institute RAS (subject 0135-20160009) and financially supported by the Russian Foundation for Basic Research (project 20-05-00308).

\section{RESEARCH ARTICLE}

Correspondence: Boris G. Golionko, golbor62@gmail.com
Received: May 18, 2019 Revised: September 29, 2020 Accepted: October 14, 2020

FOR CITATION: Golionko B.G., Ryazantsev A.V., 2021. Deformation and structural evolution of metamorphic complexes of the Taldyk antiform in the East Mugodzhar zone of Urals (West Kazakhstan). Geodynamics \& Tectonophysics 12 (1), 48-59. doi:10.5800/GT-202112-1-0511 


\title{
ДЕФОРМАЦИИ И СТРУКТУРНАЯ ЭВОЛЮЦИЯ МЕТАМОРФИЧЕСКИХ КОМПЛЕКСОВ ТАЛДЫКСКОЙ АНТИФОРМЫ ВОСТОЧНО-МУГОДЖАРСКОЙ ЗОНЫ УРАЛА (ЗАПАДНЫЙ КАЗАХСТАН)
}

\author{
Б.Г. Голионко, А.В. Рязанцев
}

\author{
Геологический институт РАН, 119017, Москва, Пыжевский пер., 7, Россия
}

АНнотАция. Рассмотрены мезоструктурные складчатые парагенезы Талдыкской антиформы (блока) Восточно-Мугоджарской зоны. Установлена последовательность их формирования и структурная эволюция изучаемого региона. В ходе проведенных исследований было выделено четыре этапа деформации. Этап DI маркируется образованием складок $\mathrm{F}_{1}$, характеризующихся северо-западным простиранием и юго-западной вергентностью. Геодинамическая природа первого этапа деформации и время его проявления пока не ясны. Формирование складок восточной вергентности $\mathrm{F}_{2}$ связано с тектоническими движениями этапа деформации DII, направленными с запада на восток. На западном крыле антиформы структуры этого этапа представлены складками, опрокинутыми в юго-восточном направлении, а на восточном - складками, погружающимися на восток и северо-восток. Образование данных структур, по-видимому, связано с субдукционно-обдукционными процессами в девоне. Надвигание Талдыкской антиформы на образования Западно-Мугоджарской зоны и образование складок западной вергентности $\mathrm{F}_{3}$ этапа DIII явились структурным выражением позднепалеозойской Уральской континентальной коллизии, завершившей геодинамическую эволюцию Уральского палеоокеана. Постколлизионные сдвиговые движения этапа деформации DIV, маркированные складками $\mathrm{F}_{4}$ с крутопадающими шарнирами, завершили структурную эволюцию района.

КЛЮЧЕВЫЕ СЛОВА: Талдыкская антиформа; Восточно-Мугоджарская зона; Восточно-Уральская мегазона; метаморфический комплекс; коллизия; структурная эволюция; этап деформации; асимметричная складка; вергентность; шарнир; осевая плоскость

ФИНАНСИРОВАНИЕ: Работа выполнена в соответствии с госзаданием ГИН РАН (тема 0135-2016-0009) при поддержке РФФИ (проект № 20-05-00308).

\section{1. ВВЕДЕНИЕ}

Изучение истории формирования структуры различных геологических комплексов - важная и интересная задача, позволяющая лучше понять их строение и геодинамическую эволюцию. Особенно важны эти исследования в познании строения и формирования метаморфических комплексов. Не будет преувеличением сказать, что их качественное и всестороннее исследование невозможно без привлечения данных структурного анализа. Одной из областей развития метаморфических комплексов является Восточно-Мугоджарская зона, являющаяся южным продолжением Восточно-Уральской мегазоны Южного Урала на территории Западного Казахстана. Метаморфические образования зоны в структурном отношении охарактеризованы слабо. Достаточно отметить, что сведения о ее структуре упоминаются лишь в одном из разделов работы [Patalakha, Slepykh, 1974], со времени опубликования которой прошло уже более 45 лет. В последнее время нами были проведены комплексные структурно-геологические исследования, позволившие уточнить строение изучаемого района и историю его деформаций. Надеемся, что данная статья позволит в какой-то мере восполнить пробел, образовавшийся в познании структуры Восточных Мугоджар.

\section{2. КРАТКИЙ ОЧЕРК ГЕОЛОГИЧЕСКОГО СТРОЕНИЯ РАЙОНА}

Как уже было отмечено выше, Восточно-Мугоджарская зона является южным продолжением Восточно-
Уральской мегазоны на территории Западного Казахстана. Зона включает в себя три блока антиформного строения (антиформы) - Талдыкский, Кайрактинский и Текельдытаусский, сложенные метаморфическими комплексами [Biryukov, 1988]. Антиформы разделены узкими грабенообразными структурами, выполненными палеозойскими осадочными и вулканогенно-осадочными породами. С запада Восточно-Мугоджарская зона граничит с Западно-Мугоджарской зоной, являющейся южным продолжением Магнитогорской мегазоны, а с востока ограничена Иргизской зоной, продолжающей на юг Зауральскую мегазону (рис. 1).

Талдыкская антиформа является самой западной в структуре Восточно-Мугоджарской зоны, ограничиваясь с запада Западно-Мугоджарской зоной, ее восточным ограничением является Балкымбайский грабен, отделяющий ее от смежной Кайрактинской антиформы [Biryukov, 1988] (рис. 1).

Антиформа сложена в основном гнейсами, гранитогнейсами среднего и кислого состава, а также амфиболитами. Протолитом для метаморфитов, вероятно, служили породы как магматического, так и вулканогенно-осадочного происхождения. В разрезе метаморфических комплексов выделяются две серии: нижняя южно-мугоджарская, в которой преобладают мигматизированные амфиболиты, и верхняя - талдыкская, сложенная кварцитами, кварц-слюдяными и кианитовыми сланцами, гнейсами, лептинитами [Milovsky et al., 1977]. Серии прорваны гранитогнейсами милысайского комплекса. Все породы претерпели метаморфизм 

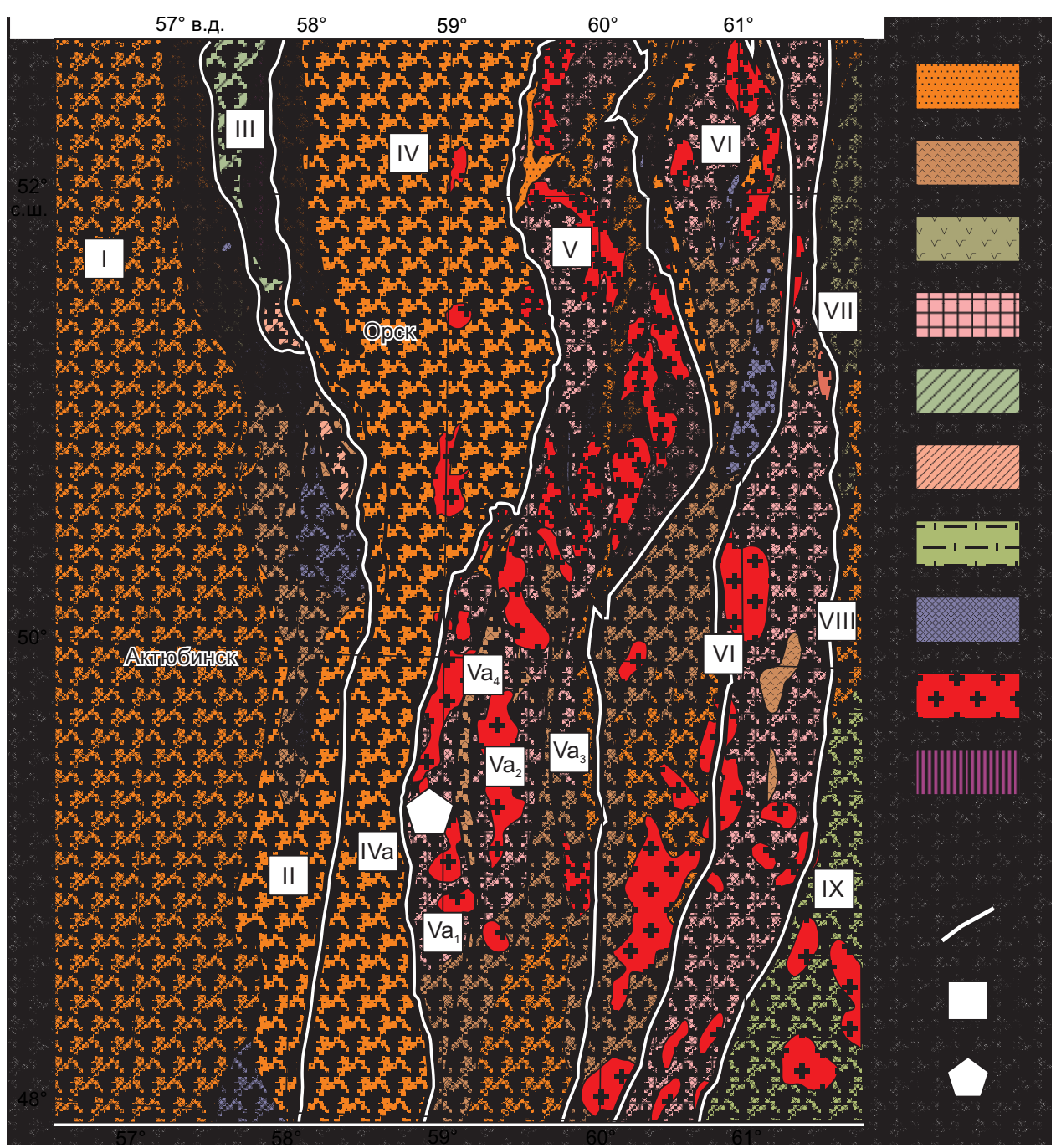

Рис. 1. Схема структурной зональности и распространения палеозойских и допалеозойских комплексов на Южном Урале (по [Ryazantsev et al., 2019], с изменениями).

Структурно-формационные зоны: I - Предуральский краевой прогиб, II - Западно-Уральская мегазона, III - Центрально-Уральская мегазона, IV - Магнитогорская мегазона, IVa - Западно-Мугоджарская зона, V - Восточно-Уральская мегазона, Va - Восточно-Мугоджарская зона: антиформы - Va - - Талдыкская, $\mathrm{Va}_{2}-$ Кайрактинская, $\mathrm{Va}_{3}$ - Текельдытаусская, $\mathrm{Va}_{4}-$ Балкымбайский грабен, VI - Зауральская мегазона, VII - Денисовская зона, VIII - Валерьяновская зона, IX - Боровская зона.

1 - разнофациальные отложения девона - верхней перми; 2 - осадочные и вулканогенные комплексы нижнего - среднего палеозоя (на востоке в ареалах амфиболитового и зеленосланцевого метаморфизма); 3 - ассоциирующий с офиолитами базальт-риолитовый комплекс верхнего ордовика на западе, нижнего ордовика на востоке; 4 - докембрийские и палеозойские образования, нерасчлененные в составе гнейсово-мигматитовых комплексов и ареалов амфиболитового и зеленосланцевого метаморфизма; 5 - докембрийские (?) и палеозойские терригенные, метаморфизованные в фации зеленых сланцев, толщи нерасчлененные; 6 - вулканогенные базальт-андезит-дацит-риолитовые толщи венда; 7 - терригенные толщи среднего ордовика - среднего девона; 8 - офиолиты и серпентинитовые меланжи; 9 - средне- и позднепалеозойские гранитоиды; 10 максютовский эклогит-глаукофансланцевый комплекс; 11 - тектонические контакты; 12 - границы структурно-формационных зон; 13 - структурно-формационные зоны; 14 - район работ.

Fig. 1. Schematic structural zoning and distribution of the Paleozoic and pre-Paleozoic complexes in the Southern Urals (modified after [Ryazantsev et al., 2019]).

Structural zones: I - Pre-Ural foredeep, II - West Ural megazone, III - Central Ural megazone, IV - Magnitogorsk megazone, IVa - West Mugodzhar zone, V - East Ural megazone, Va - East Mugodzhar zone: antiforms - Va ${ }_{1}-T_{a l d y k} V_{2}-\mathrm{Kairakta}_{2} \mathrm{Va}_{3}-\mathrm{Tekeldytaus}_{\mathrm{V}} \mathrm{Va}_{4}-$ Balkymbay graben; VI - Trans-Ural megazone, VII - Denisovka zone, VIII - Valerianovka zone, IX - Borovoe zone.

1 - Devonian - Upper Permian deposits of variable composition; 2 - sedimentary and volcanogenic complexes of the Lower-Middle Paleozoic (at the east, in the areas of amphibolite and greenshist metamorphism); 3 - basalt-rhyolite complex associated with ophiolites of the Upper Ordovician in the west, and the Lower Ordovician in the east; 4 - Precambrian and Paleozoic rocks undivided within gneissmigmatite complexes and areas of amphibolite and greenshist metamorphism; 5 - Precambrian (?) and Paleozoic undivided terrigenous rocks metamorphosed in the greenschist facies; 6 - Vendian volcanogenic basalt-andesite-dacite-rhyolite rock assemblage; 7 - Middle Ordovician - Middle Devonian terrigenous rocks; 8 - ophiolites and serpentinite melange; 9 - Middle - Late Paleozoic granitoids; 10 Maksyutovo eclogite-glaucophane-shale complex; 11 - tectonic contacts; 12 - boundaries of structural zones; 13 - structural zones; 14 - study area. 
амфиболитовой фации, имеются также свидетельства проявления высокобарического метаморфизма [Biryukov, 1988; Efimov, Burd, 1970; Rusin, 1996].

Среди амфиболитов южно-мугоджарской серии присутствуют линзы мраморов с рифейскими акритархами [Milovsky et al., 1977; Efimov, Burd, 1970]. Возраст пород южно-мугоджарской и талдыкской серий недостаточно полно охарактеризован современными геохронологическими данными. Для амфиболитов южномугоджарской серии на р. Олыталдык, согласно датировкам по K-Ar методу, имеются значения возраста 750 млн лет, а для гнейсов талдыкской серии - 530590 млн лет [Milovsky et al., 1977].

Данные цирконовой (U-Pb TIMS) геохронологии, которые сами авторы [Krasnobaev, Davydov, 1999; Krasnobaev, Bayanova, 2006] расценивают как предварительные, представляют результаты анализа по нескольким фракциям из семи проб, отобранных из разных структурно-вещественных комплексов района. Монофракции цирконов из биотит-гранат-амфиболового гнейса талдыкской серии в точке 89 (рис. 2) имеют возраст 660-689 млн лет.

K-Ar возраст гранитоидов милысайского комплекса 515 млн лет [Milovsky et al., 1977]. Близкие значения (509 млн лет) получены в точке 90 (рис. 2) U-Pb TIMS методом по цирконам [Krasnobaev, Davydov, 1999].

Наиболее высокое структурное положение имеет кварцитофиллитовая толща с уровнями графитистых кварцитов и кварцитосланцев (мамбеткульская и борлинская свиты), которая условно относится к нижнему палеозою. На севере Мугоджар в аналогичной толще обнаружены микропроблематики кембрия [Efimov, Burd, 1970].

Западная граница Талдыкской антиформы представляет собой надвиг. По нему метаморфиты последней надвинуты на образования Западно-Мугоджарской зоны, в которой распространены офиолиты и девонские островодужные комплексы. Вблизи границы на западном крыле антиформы протягивается серия линз ультрабазитов, представляющих собой приразломные синформы и тектонические чешуи. Ультрабазиты содержат многочисленные будины эклогитоподобных гранат-пироксеновых амфиболитов с высокотемпературными и высокобарическими парагенезисами [Efimov, Burd, 1970; Rusin, 1996]. В породах талдыкской серии вблизи тел ультрабазитов присутствуют высокобарические минеральные парагенезисы с гранатом и кианитом [Rusin, 2004], а амфиболиты южно-мугоджарской серии содержат линзы амфиболизированных эклогитов [Biryukov, 1988; Rusin, 2004].

Балкымбайский грабен, ограничивающий Талдыкскую антиформу с востока, выполнен осадочными и вулканогенно-осадочными породами в возрастном диапазоне от раннего палеозоя до позднего карбона [State Geological Map..., 1957]. Граница антиформы с грабеном не обнажена, но, несомненно, имеет дизъюнктивную природу. В структуре Балкымбайского грабена протягиваются многочисленные линзы серпентинизированных ультрабазитов, в которых присутствует глаукофан [Biryukov, 1988].

О возрасте метаморфизма в Восточных Мугоджарах можно судить по данным U-Pb TIMS [Krasnobaev, Davydov, 1999; Krasnobaev, Bayanova, 2006] исследования по цирконам из гнейсов тулепсайской толщи южно-мугоджарской серии, которые слагают линзы среди амфиболитов с телами эклогитов. Для этих пород из точки 91 (рис. 2) имеется конкордантное значение возраста 420 млн лет, которое, вероятно, определяет возраст метаморфизма. В работе [Krasnobaev, Davydov, 1999] также представлена интегральная (по нескольким пробам) оценка возраста метаморфизма по пересечению дискордии с конкордией и значением $t=415 \pm 14$ млн лет. В работе [Krasnobaev, Bayanova, 2006] изучались цирконы из гнейсов южно-мугоджарской серии южнее территории, показанной на рис. 2. При этом нижнее пересечение дискордии с конкордией в одной пробе дало $t=417 \pm 31$ млн лет, а в другой $t=373 \pm 4$ млн лет. Эти значения, по мнению авторов [Krasnobaev, Bayanova, 2006], свидетельствуют о метаморфизме, проявленном в среднем палеозое.

Метаморфические комплексы прорваны позднепалеозойскими массивами гранитов, жилами и дайками гранит-порфиров, долеритов и пегматитами [State Geological Мар...,1957].

С эволюцией структуры района связано формирование месторождений антофиллит-асбеста, кианита и мусковит-полевошпатовых пегматитов (рис. 2).

\section{3. ДАННЫЕ СТРУКТУРНОГО АНАЛИЗА}

Строение Талдыкской антиформы изучалось в верхнем и среднем течении р. Олыталдык и в среднем течении р. Милысай. Структурные исследования заключались в изучении плоскостных и линейных элементов мезоскладок (т.е. складок, наблюдаемых в пределах обнажения) на обоих крыльях Талдыкской антиформы, а также на ее границе с Западно-Мугоджарской зоной и в пределах Балкымбайского грабена. В ходе изучения выделялись разновозрастные генерации складок и их взаимоотношения. Методика мезоструктурных исследований неоднократно была изложена в отечественной [Kazakov, 1976] и иностранной литературе [Turner, Weiss, 1963; Ramsay, Huber, 1987]. Построение структурных диаграмм производилось при помощи программы Stereo32.

Структура Талдыкской антиформы представляет собой крупную брахиантиклинальную складку с соотношением длины и ширины, равным 1:3, вытянутую в северо-северо-восточном направлении на 90 км. На изученном участке западное крыло антиформы сложено амфиболитами, которые к востоку сменяются толщей гранитогнейсов, биотитовых, двуслюдяных, реже амфиболовых гнейсов с подчиненным количеством амфиболитов и кварцитов. Эта толща частично слагает западное крыло и центральную часть антиформы, где в ее составе появляются гранат-амфиболовые гнейсы. Восточное крыло структуры в изученном районе сложено 


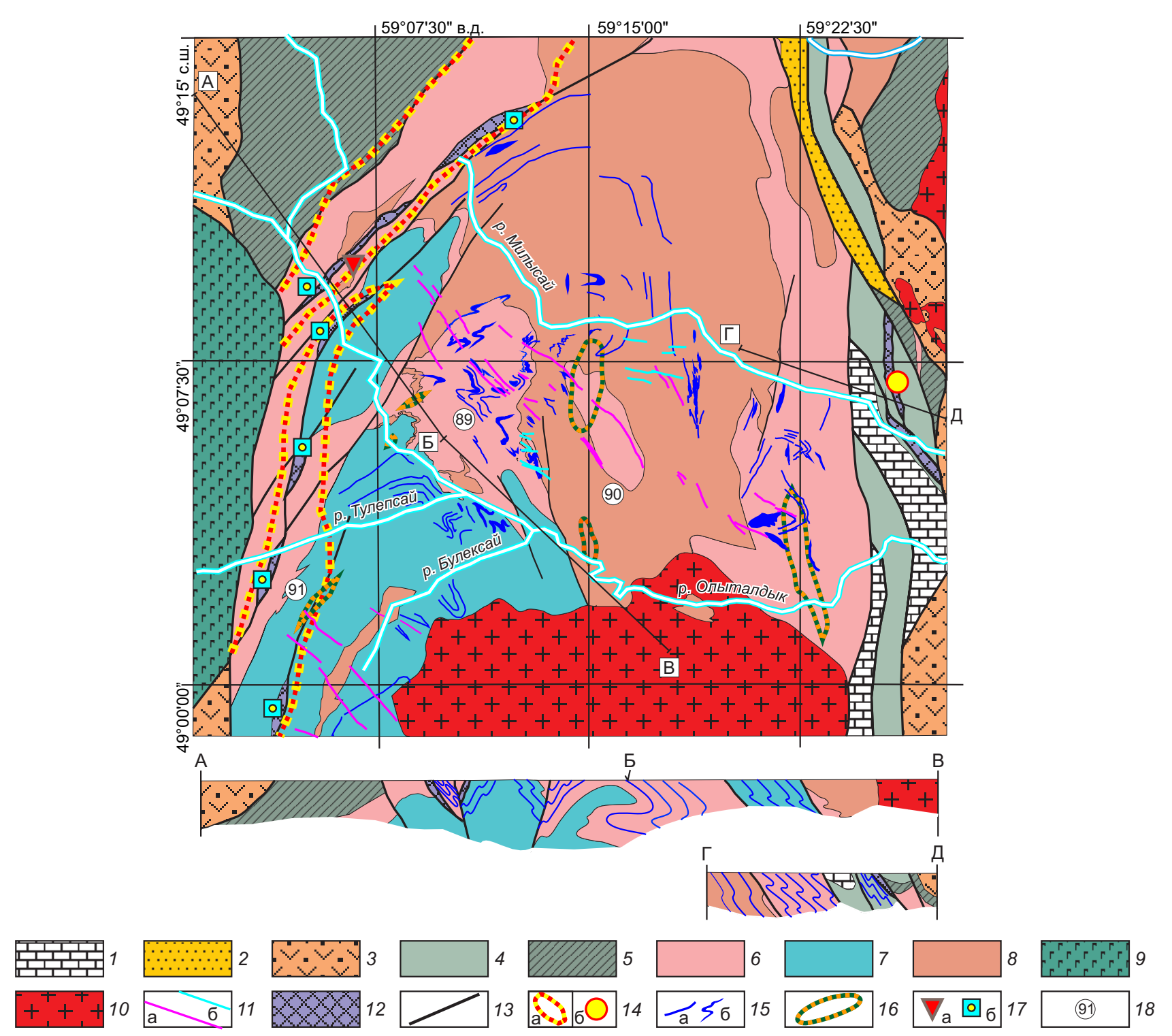

Рис. 2. Схема геологического строения Талдыкской антиформы в бассейне рек Олыталдык и Милысай (составлено с использованием данных [Milovsky et al., 1977], с дополнениями и изменениями).

1-2 каменноугольные толщи: 1 - известняки, 2 - балаталдыкская свита, конгломераты, песчаники и алевролиты; 3 - вулканогенные толщи, нижний - средний девон; 4 - тоймонская и шебектинская свиты нерасчлененные, ордовик, базальты, туффиты, кремни, андезиты, дациты, их туфы; 5 - борлинская и мамбеткульская свиты нерасчлененные, нижний палеозой (?), углеродистые сланцы, кварциты, филлиты; 6 - талдыкская серия, верхний рифей - венд (?), кварциты, кварц-мусковитовые сланцы, кианитовые сланцы, двуслюдяные гнейсы; 7 - южно-мугоджарская серия, рифей (?), амфиболиты, эклогиты; 8 милысайский комплекс, венд - нижний кембрий (?), гранитогнейсы; 9 - актогайский комплекс параллельных долеритовых даек с базальтами и габбро в скринах, ранний - средний девон; 10 - ащисайский комплекс, средний карбон, порфировидные биотитовые и биотит-роговообманковые граниты; 11 - позднепалеозойские (?) дайки и жилы гранит-порфиров (a) и долеритов (б); 12 - ультрабазиты; 13 - разрывные нарушения; 14- ареалы высокобарического метаморфизма (а), участки глаукофанизированных пород (б); 15 - линии простирания (а) и замыкания складок (б); 16 - поля мусковит-полевошпатовых пегматитов; 17 - месторождения и проявления кианита (a) и антофилит-асбеста (б); 18 - точки проб для определения U-Pb возраста и их номера из работы [Krasnobaev, Davydov, 1999].

Fig. 2. Schematic geological structure of the Taldyk antiform located in the basin of the Olytaldyk and Milysay rivers (using the data from [Milovsky et al., 1977], with additions and modifications).

1-2 - Carboniferous strata: 1 - limestone, 2 - Balataldyk formation, conglomerate, sandstone and siltstone; 3 - Lower - Middle Devonian volcanic rocks; 4 - Toymon and Shebekta formations, undivided, Ordovician, basalt, tuffite, chert, andesite, dacite, tuff; 5 - Borlino and Mambetkul formations, undivided, Lower Paleozoic (?), carbonaceous schist, quartzite, phyllite; 6 - Taldyk group, Upper Riphean Vendian (?), quartzite, quartz-muscovite schist, kyanite schist, two-mica gneiss; 7 - South Mugodzhar group, Riphean (?), amphibolite, eclogite; 8 - Milysay complex, Vendian - Lower Cambrian (?), granite gneiss; 9 - Aktogay complex of parallel dolerite dikes with basalt and gabbro in screen shots, Early-Middle Devonian; 10 - Ashchisai complex, Middle Carbon, porphyritic biotite and biotite-hornblende granite; 11 - Late Paleozoic (?) dikes and veins of granite-porphyry (a) and dolerite (б); 12 - ultrabasite; 13 - faults; 14 - areas of highpressure metamorphism (a), areas of glaucophanized rocks (б); 15 - lines of trends (a) and closure of folds (б); 16 - muscovite-feldspar pegmatite field; 17 - deposits and occurrences of kyanite (a) and anthophyllite-asbestos (б); 18 - sample points for U-Pb dating and their numbers (from [Krasnobaev, Davydov, 1999]). 
мигматизированными амфиболитами, к востоку сменяющимися монотонной толщей гранитогнейсов, прорванной позднепалезойскими гранитоидами. В эндоконтактовой зоне гранитоиды содержат ксенолиты гранитогнейсов и амфиболитов.

Усредненное падение западного крыла антиформы, достигающее $60^{\circ}$, несколько превышает падение ее восточного крыла $\left(50^{\circ}\right)$, хотя в целом структуру нельзя определить как типично асимметричную [Golionko, Ryazantsev, 2020].

Наиболее ранними структурными элементами Талдыкской антиформы являются чрезвычайно редко встречающиеся мелкие изоклинальные складки $\mathrm{F}_{1}$, развитые в послойных мигматитах, локализованных в амфиболитах на западном крыле структуры (рис. 3, а). Ранние складчатые структуры деформированы более поздними складками $\mathrm{F}_{2}$. Шарниры складок $\mathrm{F}_{1}$ полого погружаются в северо-западном и юго-восточном направлении. По-видимому, к этой же генерации относятся и колчановидные складки, развитые в ядре антиформы в гранат-амфиболовых гнейсах (рис. 3, б). Эти структуры также развиты на крыльях более поздних складок $\mathrm{F}_{2}$. Азимуты падения шарниров складок $\mathrm{F}_{1}$ и параллельной им линейности меняются от северо-восточного до северо-западного направления, что, очевидно, объясняется наложением более поздних деформаций.

Следующая генерация пликативных структур наиболее развита в пределах изучаемой брахиантиформы. Это асимметричные зигзагообразные складки, отмеченные на обоих крыльях основной структуры, варьирующиеся от открытых до практически изоклинальных, причем сжатые, изоклинальные формы резко преобладают. (a)

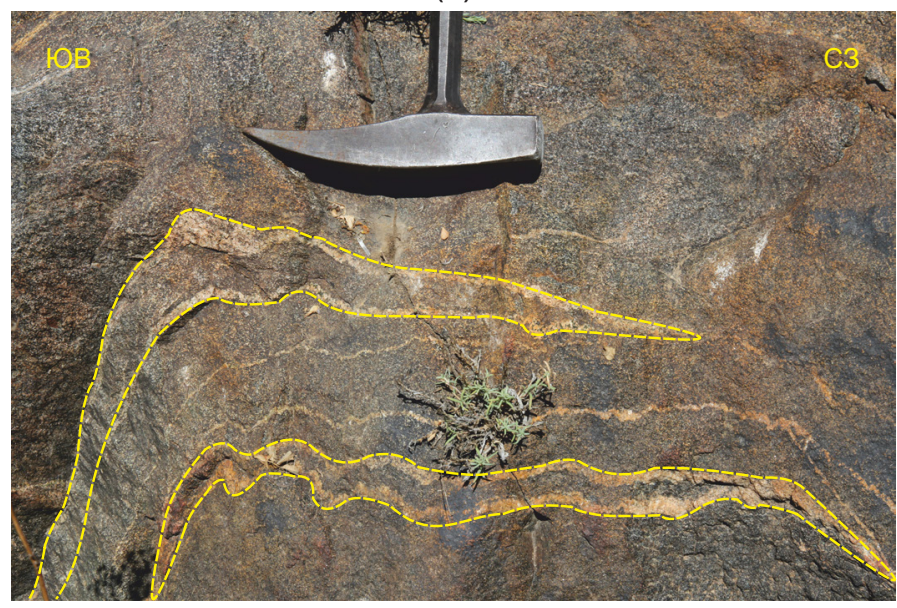

(6)

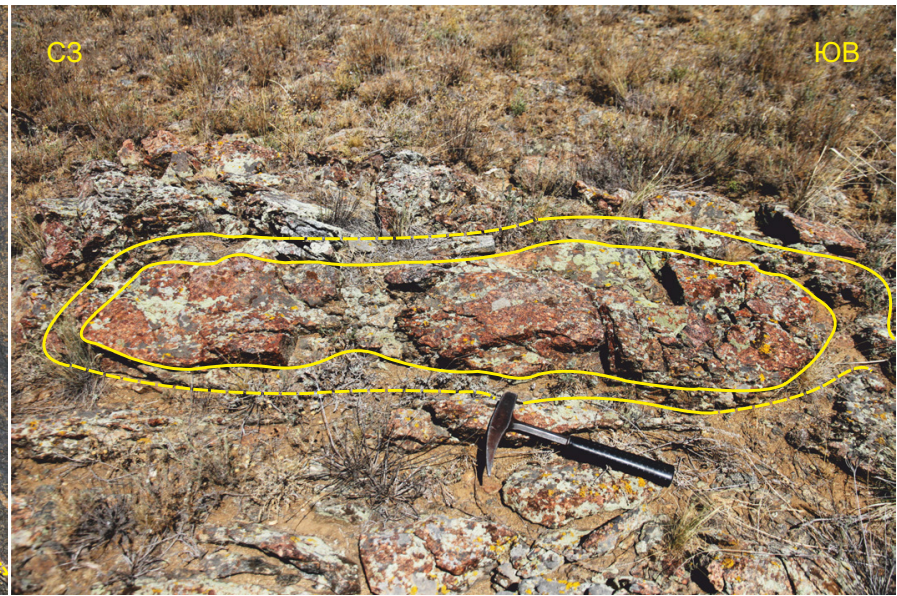

Рис. 3. Складки $\mathrm{F}_{1}$ на западном крыле антиформы в мигматизированных амфиболитах $(a)$ и в гранат-амфиболовых гнейсах в ядре структуры (б).

Fig. 3. Folds $\mathrm{F}_{1}$ in the western limb of the antiform in migmatized amphibolite $(a)$ and in garnet-amphibole gneiss in the structure's core (б).

(a)

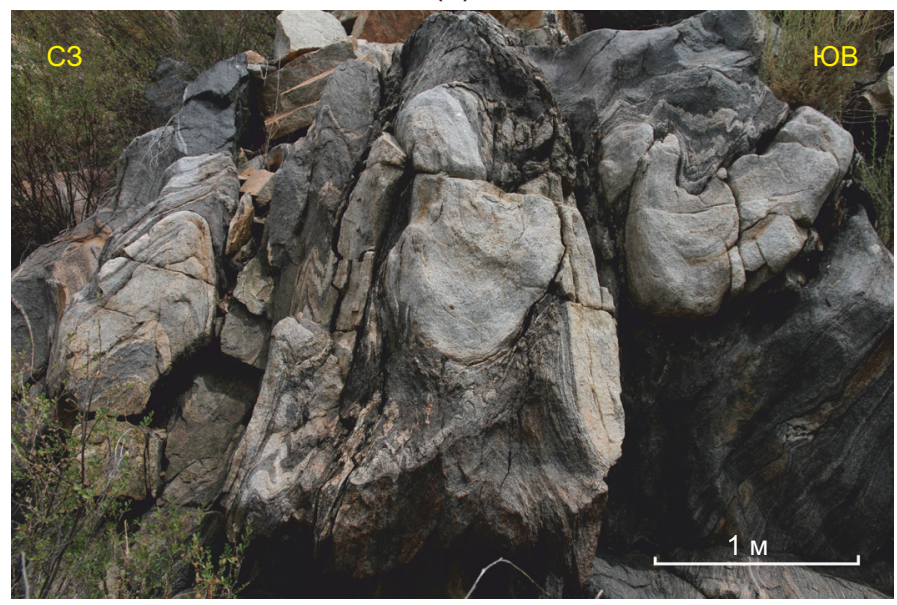

(6)

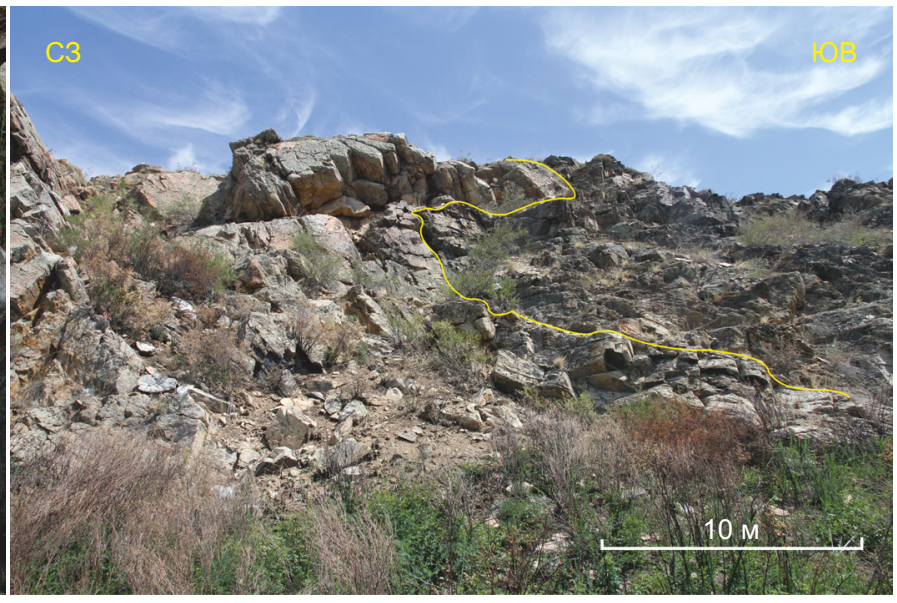

Рис. 4. Складки $\mathrm{F}_{2}$, опрокинутые на юго-восток, западное крыло Талдыкской антиформы (a) и ядро структуры (б).

Fig. 4. Folds $\mathrm{F}_{2}$ overturned to the south-east in the western limb of the Taldyk antiform ( $a$ ), and the structure's core (б). 
На западном крыле брахиантиформы складки $\mathrm{F}_{2}$ опрокинуты на юго-восток и характеризуются юго-восточной вергентностью, за исключением случаев, когда они осложняют крыло более крупной асимметричной открытой складки, круто (60-75) погружающейся на юго-восток (рис. 4, а). Наблюдаемый в обнажениях горизонтальный размах крыльев меняется от 5-10 см до 15-20 м. Судя по косвенным признакам (смена рисунка мелких дополнительных складок), размах структур может достигать 0.5 км. Верхние и нижние крылья структур падают на северо-запад под углом 25-78, а смыкающиеся круто (65-85) падают на юго-восток либо погружаются на северо-запад под углами 35-80 в опрокинутом залегании. Часто наблюдаются срывы по осевой поверхности складок. Ближе к центральной части антиформы осевые плоскости этих складок изгибаются в восточном направлении таким образом, что вверх по восстанию осевой плоскости складка из опрокинутой превращается в лежачую (рис. 4, б). Здесь же наблюдаются зоны катаклазитов и бластомилонитов, развитых по контакту мусковитовых гнейсов и гранатамфиболовых гнейсов, слагающих ядро основной структуры. Шарниры складок юго-восточной вергентности полого (5-30) погружаются в северо-восточном и югозападном направлении (рис. 5, а).

Структуры восточного крыла Талдыкской антиформы наблюдались в среднем течении рек Милысай и Олыталдык. Здесь складки $\mathrm{F}_{2}$ относительно небольшие, (a)

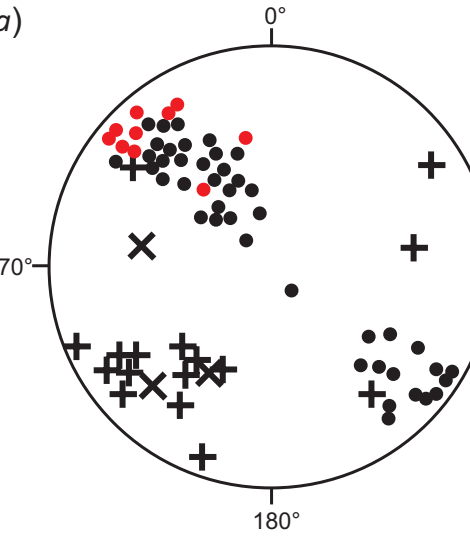

(2)

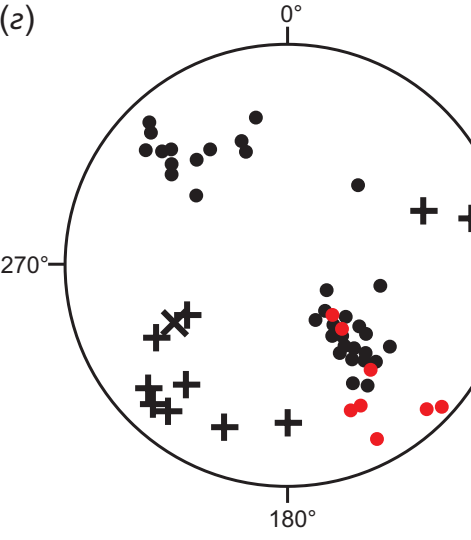

(б)

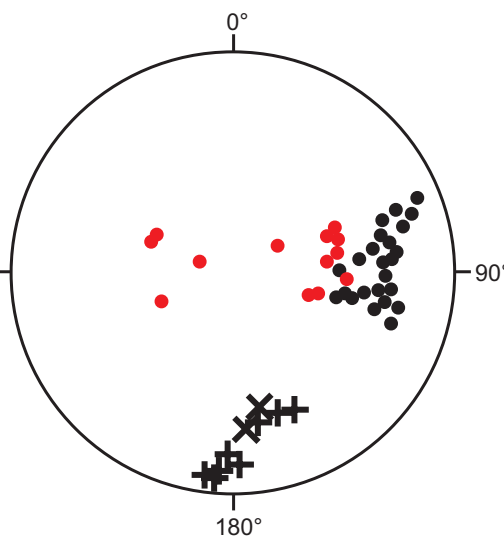

(d)

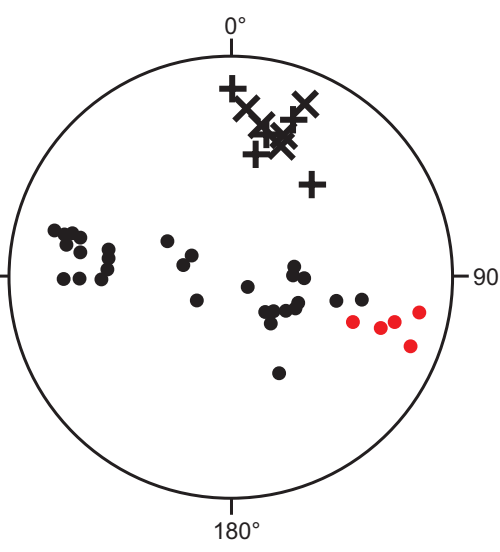

(e)
(8)

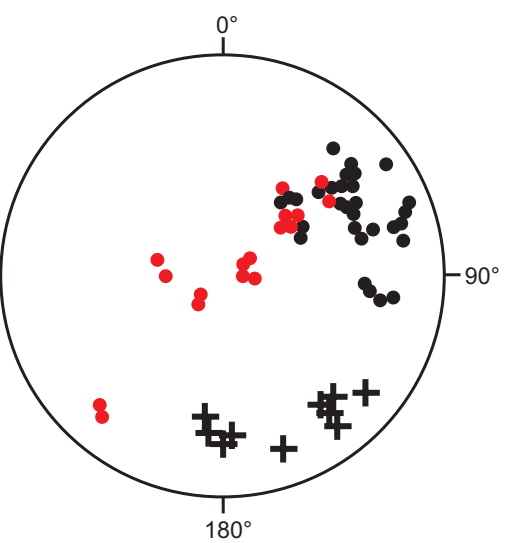

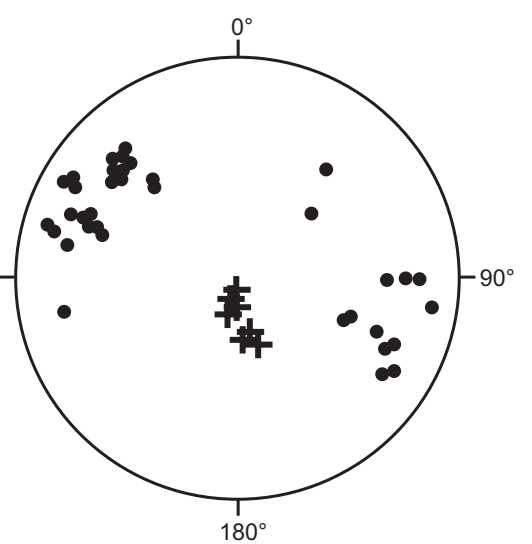

Рис. 5. Стереограммы элементов залегания полюсов сланцеватости и полосчатости, слоистости, шарниров и линейности в складках, изученных в пределах Талдыкской антиформы:

$(a)$ - в складках юго-восточной вергентности $\mathrm{F}_{2}$ на западном крыле антиформы - 82 замера, $\left(б\right.$, ) - в ныряющих складках $\mathrm{F}_{2}$ на восточном крыле антиформы в долинах рек Милысай (б) - 53 замера и Олыталдык (в) - 64 замера, (2, д) - в складках западной вергентности $\mathrm{F}_{3}$ на границе Талдыкской антиформы и Западно-Мугоджарской зоны (2) - 62 замера и в Балкымбайском грабене $(\partial)-44$ замера, $(e)$ - в сдвиговых складках с крутопадающими шарнирами $\mathrm{F}_{4}-43$ замера.

1 - полюсы сланцеватости и слоистости, нормальные залегания; 2 - полюсы сланцеватости и слоистости, опрокинутые залегания; 3 - шарниры складок; 4 - линейность. Равноугольная проекция, верхняя полусфера.

Fig. 5. Stereograms of schistosity and stratification poles, hinges and lineation in folds studied within the Taldyk antiform:

(a) - in folds $\mathrm{F}_{2}$ with SE-vergence in the western limb of the antiform (82 measurements), $(6,8)-$ in recumbent folds $\mathrm{F}_{2}$ in the eastern limb of the antiform in the Milysay river valley (6) (53 measurements) and Olytaldyk river valley $(8)(64$ measurements), ( $2, \partial)-$ in folds $\mathrm{F}_{3}$ with $\mathrm{W}$-vergence at the boundary between the Taldyk antiform and the West Mugodzhar zone (2) (62 measurements), and in the Balkymbay graben $(\partial)$ (44 measurements), $(e)$ - in shear folds $\mathrm{F}_{4}$ with steeply dipping hinges (43 measurements).

1 - schistosity and stratification poles, normal bedding; 2 - schistosity and stratification poles, overturned bedding; 3 - fold hinges; 4 - lineation. Equal angle projection, upper hemisphere. 
размах крыльев структур не превышает первые метры. По морфологии это также асимметричные складки, от открытых до изоклинальных. Все они являются ныряющими, за исключением мелких складок, осложняющих смыкающиеся крылья более крупных открытых складчатых структур, а также симметричных М-складок, развитых в ядрах пликативных структур (рис. 6, а). Верхние и нижние крылья складок и их осевые плоскости в долине р. Олыталдык погружаются в северовосточном, а в долине р. Милысай в восточном направлении под углом 50-70. Смыкающиеся опрокинутые крылья погружаются в том же направлении, но под более пологими углами в сжатых и изоклинальных складках, а в открытых флексурообразных структурах углы падения смыкающихся крыльев превышают углы падения верхних и нижних крыльев складки. Шарниры структур полого (2-20) погружаются в северном направлении в долине р. Милысай и в северном и северо-западном направлении в долине р. Олыталдык (см. рис. 5, б, в). Таким образом, мы наблюдаем переход от складок, опрокинутых на юго-восток на западном крыле антиформы, к лежащим в ее ядре и погружающимся на восток и северо-восток на восточном крыле основной структуры. Очевидно, что вне зависимости от того, на каком из крыльев региональной структуры наблюдаются складки $\mathrm{F}_{2}$, они везде фиксируют одно и то же направление перемещения в восточных румбах, что однозначно указывает на то, что формирование этих складок предшествовало образованию самой брахиантиформы. По всей видимости, различия в направлении погружения складок в северной и южной части восточного крыла основной структуры связаны с влиянием более поздних деформаций.

К следующей возрастной генерации относятся складки $\mathrm{F}_{3}$, развитые на границе Талдыкского блока с Западно-Мугоджарской зоной и в Балкымбайском грабене. В Балкымбайском грабене структуры изучались в кремнях раннепалеозойского возраста, а на границе Восточно-Мугоджарского поднятия и Западно-Мугоджарской зоны - в гнейсах и амфиболитах Талдыкского блока. В обеих структурах это асимметричные складки западной вергентности. На западной границе Талдыкской антиформы развиты асимметричные зигзагообразные складки, от открытых до изоклинальных, опрокинутые на северо-запад (рис. 6, б). Изоклинальные структуры преобладают, в то время как открытые встречаются довольно редко. Чаще всего наблюдаются обрывки складок, сорванные по осевым плоскостям, разделенные зонами катаклаза и милонитизации (рис. 6, б). Наблюдаемые складки довольно мелкие, горизонтальный размах структур не превышает 50 см. Пологие крылья структур погружаются на юго-восток (25-60²), (a)

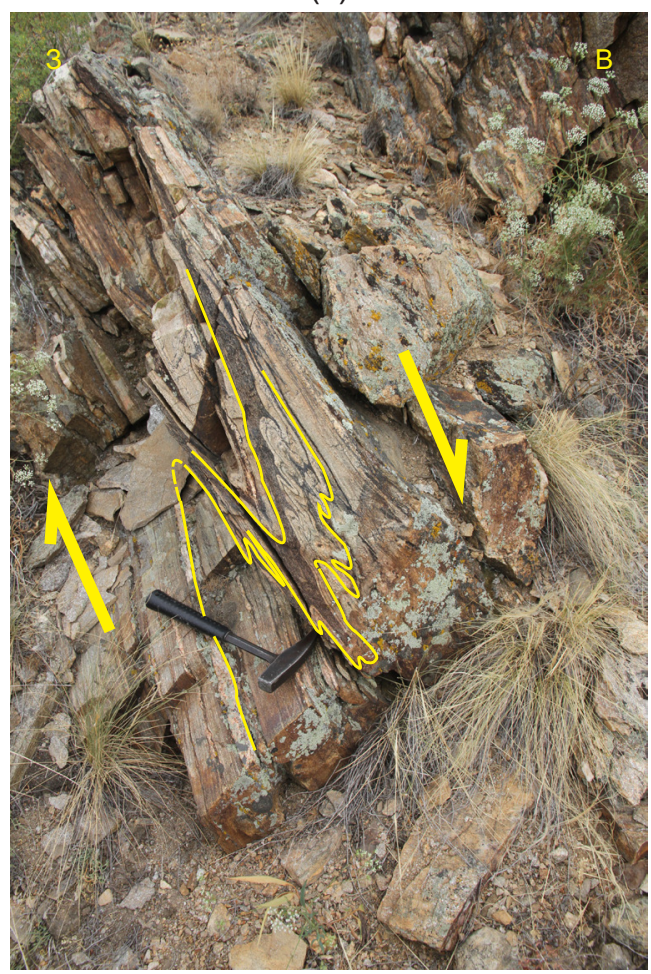

(б)

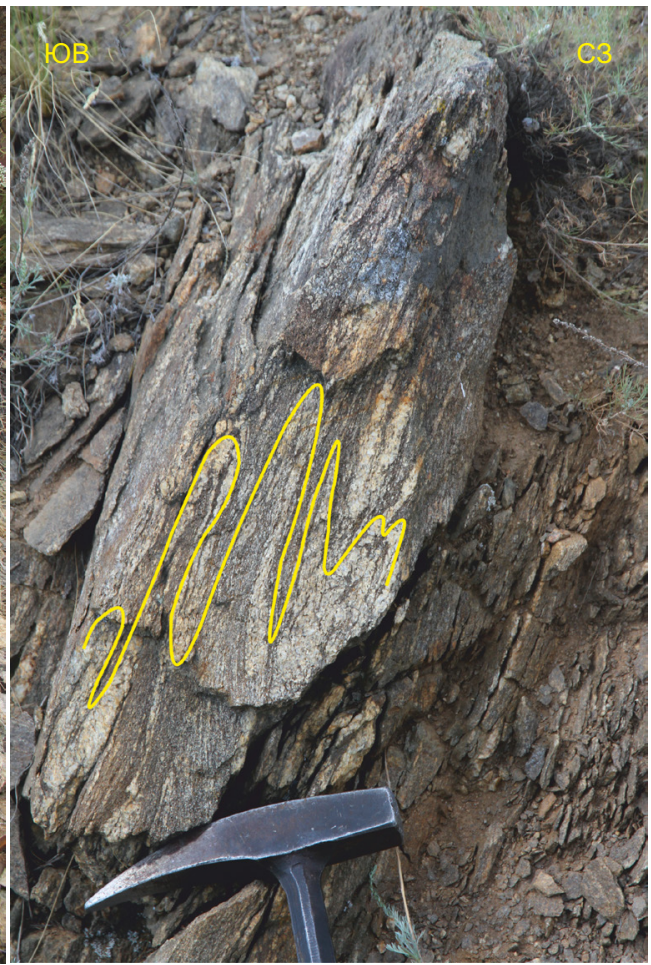

Рис. 6. Складки второго и третьего этапа деформации в метаморфических породах Талдыкской антиформы:

$(a)$ - ныряющие складки $\mathrm{F}_{2}$, восточное крыло антиформы, среднее течение р. Милысай; (б) - складки западной вергентности $\mathrm{F}_{3}$, граница антиформы и Западно-Мугоджарской зоны, верхнее течение р. Олыталдык.

Fig. 6. Folds formed at the second (DII) and third (DIII) stages of deformation in the metamorphic rocks of the Taldyk antiform: $(a)$ - recumbent folds $\mathrm{F}_{2}$ in the east limb of the antiform at the middle course of the Milysay river; (6) - folds $\mathrm{F}_{3}$ with $\mathrm{W}$-vergency at the boundary between the antiform and the West Mugodzhar zone at the upper course of the Olytaldyk river. 
крутопадающие - на северо-запад (65-80), а опрокинутые на юго-восток - под углом 30-85․ Шарниры структур полого погружаются в юго-западном и северо-восточном направлении (см. рис. 5, г).

В Балкымбайском грабене это открытые складки, опрокинутые в западно-северо-западном направлении (рис. 7, a), пологие крылья которых погружаются на восток-юго-восток под углами 8-35, а крутопадающие - на запад-северо-запад под углами 60-80 или на восток-юго-восток $\left(65-85^{\circ}\right)$ в опрокинутом залегании. Шарниры структур полого погружаются в югоюго-западном направлении (см. рис. 5, д). К этой же генерации складчатых структур, очевидно, относится и сама антиформа. В качестве дополнительных складок, связанных с ее формированием, могут рассматриваться открытые флексурообразные перегибы западной вергентности на восточном крыле структуры, наблюдавшиеся в среднем течении р. Олыталдык. Что же касается западного крыла антиформы, где дополнительные складки должны иметь восточную вергентность, то выделить их в области интенсивного развития складок $\mathrm{F}_{2}$ юго-восточной вергентности не представляется возможным.

Следующая генерация представлена типичными сдвиговыми складками $\mathrm{F}_{4}$ с шарнирами, круто $\left(60-85^{\circ}\right)$ погружающимися в северном и север-северо-западном направлении (рис. 7, б). Крылья этих структур круто (55-85) погружаются в северо-западном, северо-восточном, восточном и юго-восточном направлении (см. рис. 5, е). По кинематике складки с крутопадающими шарнирами являются правосдвиговыми. Очевидно, что именно со складками этого этапа связаны вариации в ориентировках складок предыдущих генераций. Сдвиговые складки $\mathrm{F}_{4}$ встречаются относительно редко, что, по всей видимости, связано с условиями обнаженности, поскольку наблюдаемые различия в ориентировках складок $\mathrm{F}_{2}$ и $\mathrm{F}_{3}$ в разных частях антиформы предполагают широкое развитие сдвиговых деформаций.

\section{4. ОБСУЖДЕНИЕ РЕЗУЛЬТАТОВ}

Подводя итог всему вышесказанному, можно выдвинуть следующие предположения о структурной эволюции геодинамических обстановок формирования комплексов Талдыкского блока.

Имеющиеся на сегодняшний день данные по Южному Уралу позволяют реконструировать вендскокембрийскую активную континентальную окраину [Ryazantsev et al., 2019]. В Восточных Мугоджарах комплексы этой окраины представляет южно-мугоджарская и талдыкская серия и прорывающие их гранитогнейсы милысайского комплекса. Активный режим развития окраины нестабильно продолжался вплоть до начала силура. В конце силура и в девоне на пассивной окраине происходят аккреционные процессы, связанные с субдукцией и обдукцией при коллизии с островодужными системами. С этим временем связано тектоническое совмещение комплексов океанической и континентальной литосферы, сопровождавшееся проявлением высокобарического метаморфизма. На этой стадии образован максютовский эклогит-глаукофансланцевый комплекс и гранулитовые комплексы в подошвах офиолитовых аллохтонов. Диапазон пикового метаморфизма максютовского комплекса 375 (?)384-411 млн лет [Beane, Leech, 2007; Lepezin et al., 2006; Fed'kin, 2018; и ссылки в этих работах]. Диапазон гранулитового метаморфизма 392-416 млн лет [Ryazantsev et al., 2020; и ссылки в этой работе]. Метаморфизм в Талдыкском блоке характеризуется значениями 417 \pm 31 и $373 \pm 4$ млн лет и, вероятно, связан с подошвой (a)

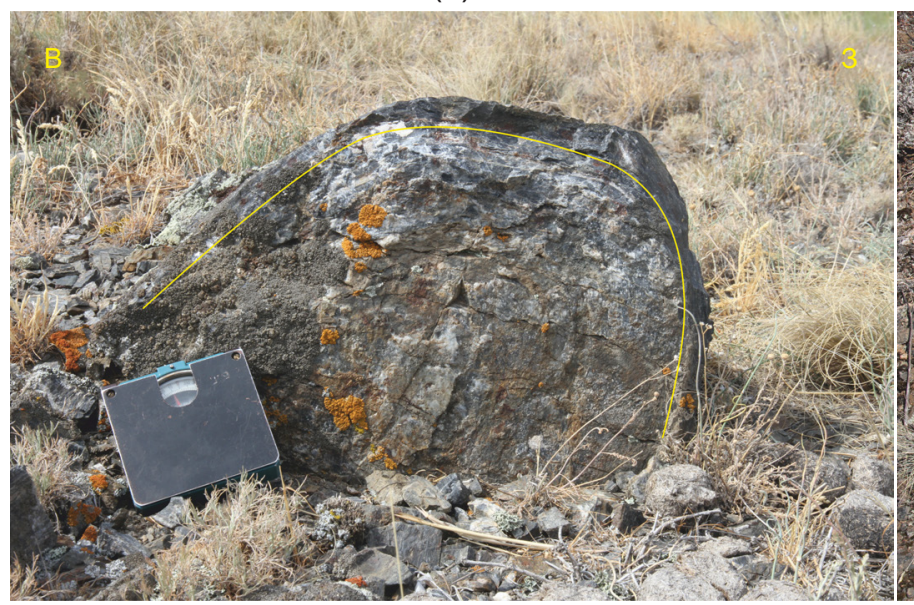

(б)

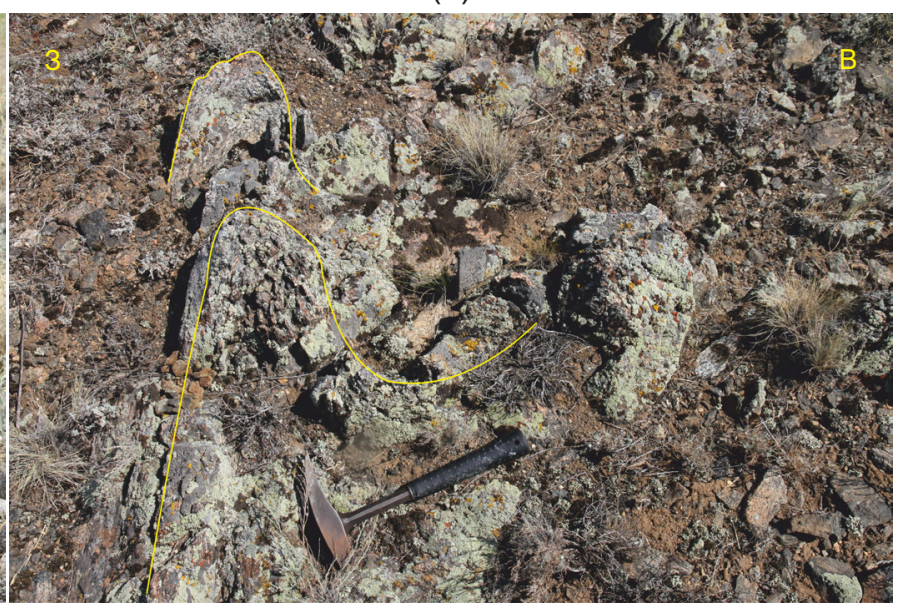

Рис. 7. Складки третьего и четвертого этапа деформации:

$(a)$ - складки западной вергентности $\mathrm{F}_{3}$, Балкымбайский грабен, среднее течение р. Милысай, (б) - сдвиговые складки $\mathrm{F}_{4}$, долина р. Олыталдык.

Fig. 7. Folds formed at the third (DIII) and fourth (DIV) stages of deformation:

$(a)$ - folds $\mathrm{F}_{3}$ with $\mathrm{W}$-vergency in the Balkymbay graben at the middle course of the Milysay river; (б) - shear folds $\mathrm{F}_{4}$ in the Olytaldyk river valley. 
офиолитовых аллохтонов и, по-видимому, проявлен в техже геодинамических обстановках, что и метаморфические комплексы аналогичного возраста в западных структурных зонах Южного Урала. После коллизии дуга - континент аккретированная окраина в конце девона - карбоне стала развиваться в активном режиме с образованием вулканоплутонического пояса [Fershtater, 2013], который в Талдыкской антиформе представлен гранитоидными массивами и жильными интрузиями. С коллизией в конце перми связано формирование аллохтонов, перемещение которых происходило в основном с востока на запад.

Немногое можно сказать об условиях формирования складок $\mathrm{F}_{1}$ ввиду их малого распространения. Существующие наблюдения предполагают их юго-западную вергентность в современной структуре. Однако в условиях недостаточной статистики и с учетом последующих деформаций можно лишь утверждать, что их ориентировка ортогональна к ориентировке складок $\mathrm{F}_{2}$. Вергентность последних меняется от юго-восточной на западном крыле Талдыкской антиформы до северо-восточной и восточной на ее восточном крыле. Таким образом, в целом складки $\mathrm{F}_{2}$ обладают вергентностью в восточных румбах, а ортогоналные им $\mathrm{F}_{1}$ - в южных. С некоторой долей условности можно считать, что этап деформаций DI связан с образованием субширотных складок $\mathrm{F}_{1}$. Наличие ранних субширотных складок и наложение на них складок субмеридиональной ориентировки были установлены по результатам крупномасштабной инструментальной геологической съемки в работе [Patalakha, Slepykh, 1974].

Определенно можно говорить об этапе деформации DII маркируемом формированием складок восточной вергентности $\mathrm{F}_{2}$. Несомненно, что образование этих структур связано с тектоническими движениями с запада на восток (рис. 8, а). Масштаб тектонических движений на этапах деформации DI, время проявления и их геодинамическую природу еще предстоит установить.

Этап формирования складок с восточной вергентностью распространен в западных зонах Южного Урала и связывается с субдукционно-обдукционными процессами в девоне [Golionko, Ryazantsev, 2017]. Также можно условно интерпретировать обстановки формирования складок этой генерации и в Талдыкской антиформе.

Этап деформаций DIII, выразившийся в формировании складок западной вергентности $\mathrm{F}_{3}$, несомненно, связан с тектоническими движениями позднепалеозойского возраста, направленными с востока на запад (рис. 8, б). Эти структуры хорошо известны в пределах Уральской складчатой области и связаны с позднепалеозойской континентальной коллизией, завершившей геодинамическую эволюцию Уральского палеоокеана [Golionko, Ryazantsev, 2018]. С этим этапом, по всей видимости, связано и формирование самой антиформы. Отсутствие наблюдаемой интерференции складок $\mathrm{F}_{2}$ и $\mathrm{F}_{3}$ может быть связано с условиями обнаженности

(a)

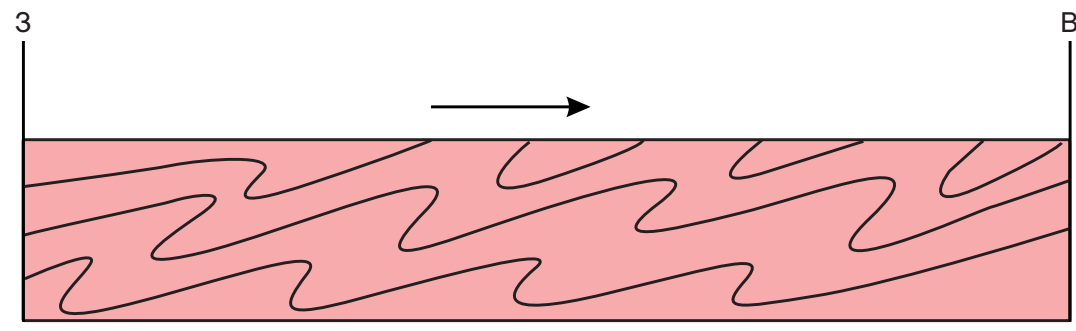

(б)

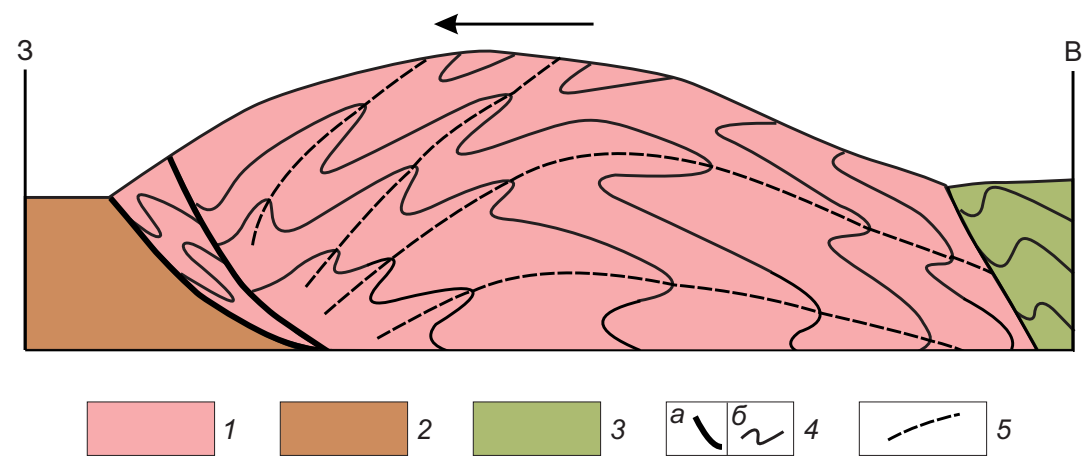

Рис. 8. Графическая модель образования структуры Талдыкской антиформы на этапах дефомации DII (a) и DIII (б).

1 - метаморфические комплексы Талдыкской антиформы; 2 - породы Западно-Мугоджарской зоны; 3 - породы Балкымбайского грабена; 4 - надвиги (а), структурные линии в породах Талдыкской антиформы и Балкымбайского грабена (б); 5 - следы осевых плоскостей в структурах Талдыкской антиформы.

Fig. 8. Graphic model showing the structure formation of the Taldyk antiform at the second (DII, $a$ ) and third (DIII, б) stages of deformation.

1 - metamorphic complexes of the Taldyk antiform; 2 - rocks of the West Mugodzhar zone; 3 - rocks of the Balkymbay graben; 4 thrusts (a), structural lines in the rocks of the Taldyk antiform and Balkymbay graben (б); 5 - traces of axial planes in the structures of the Taldyk antiform. 
в изучаемом районе, поскольку непосредственно в зоне контакта Восточно- и Западно-Мугоджарской зон складки $\mathrm{F}_{2}$ были полностью переработаны, а далее к востоку область динамического влияния этого контакта не обнажена.

Складки с крутопадающими шарнирами $\mathrm{F}_{4}$, деформирующие ранее образованные структуры, отвечают этапу деформации DIV. Складки этого типа широко распространены во всех структурно-формационных зонах Урала, большинство исследователей связывают их с постколлизионными сдвиговыми движениями, окончательно оформившими структурный облик изучаемого региона [Tevelev, 2003; Znamensky, Znamenskaya, 2009; Golionko, Ryazantsev, 2017].

\section{5. ЗАКЛЮЧЕНИЕ}

В результате проведенных работ в структурной эволюции Талдыкской антиформы Восточно-Мугоджарской зоны было установлено четыре этапа деформаций. Этап DI связан с формированием субширотных складок южной вергентности $\mathrm{F}_{1}$, которые были деформированы субмеридиональными складками восточной вергентности $\mathrm{F}_{2}$, маркирующими этап деформации DII. Образование складок западной вергентности $\mathrm{F}_{3}$ знаменует собой этап деформаций DIII, связанный с позднепалеозойской уральской континентальной коллизией.

Постколлизионные сдвиговые движения и связанные с ними складки с крутопадающими шарнирами $\mathrm{F}_{4}$ отвечают этапу деформаций DIV, завершившего главную стадию структурной эволюции региона.

\section{6. ЛИТЕРАТУРA/REFERENCES}

Beane R., Leech M., 2007. The Maksyutov Complex: The First UHP Terrane 40 Years Later. In: M. Cloos, W.D. Carlson, M.C. Gilbert, J.G. Liou, S.S. Sorensen (Eds), Convergent Margin Terranes and Associated Regions: A Tribute to W.G. Ernst. Geological Society of America Special Paper 419, p. 153-169. https://doi.org/10.1130/2006.2419(08).

Biryukov V.M., 1988. High-Pressure Complexes of Mobile Belts. Nauka, Moscow, 208 p. (in Russian) [Бирюков B.M. Высокобарические комплексы подвижных поясов. Москва: Наука, 1988. 208 с.].

Efimov I.A., Burd G.I., 1970. Regional Metamorphism, Age and Conditions of Formation of Some Deep Rocks of the Precambrian in Mugodzhar. Soviet Geology 11, 36-89 (in Russian) [Ефимов И.А., Бурд Г.И. Региональный метаморфизм, возраст и условия формирования некоторых глубинных пород докембрия Мугоджар // Советская геология. 1970. № 11. С. 36-89].

Fed'kin V.V., 2018. Four Episodes of Thermal Evolution of Eclogites of the Maksyutov Complex (South Urals). In: Problems of Magmatic and Metamorphic Petrology, Geodynamics and Genesis of Diamonds. Abstracts of the International Conference Dedicated to the 110th Anniversary of Academician V.S. Sobolev. (June 09-14, 2018). Vol. 1. SB RAS Publishing House, Novosibirsk, 72 p. (in Russian) [Федькин В.В. Четыре эпизода термальной эволюции эклогитов Максютовского комплекса (Южный Урал) //
Проблемы магматической и метаморфической петрологии, геодинамики и происхождения алмазов: Тезисы докладов Международной конференции, посвященной 110-летию со дня рождения академика В.С. Соболева (9-14 июня 2018 г.). Новосибирск: Изд-во СО РАН, 2018. T. 1.72 c.].

Fershtater G.B., 2013. Paleozoic Intrusive Magmatism of the Middle and South Urals. Editorial and Publishing Department of UB RAS, Yekaterinburg, 368 p. (in Russian) [Ферштатер Г.Б. Палеозойский интрузивный магматизм Среднего и Южного Урала. Екатеринбург: РИО УрО РАН, 2013. 368 c.].

Golionko B.G., Ryazantsev A.V., 2017. Structural Evolution of Vendian and Early-Middle Paleozoic Complexes of the Uraltau Zone and Sakmar Allochthons (South Urals). Geotectonics 3, 83-112 (in Russian) [Голионко Б.Г., Рязанцев А.В. Структурная эволюция вендских и раннесреднепалеозойских комплексов зоны Уралтау и сакмарских аллохтонов (Южный Урал) // Геотектоника. 2017. № 3. C. 83-112]. https://doi.org/10.7868/S0016853X17 030067.

Golionko B.G., Ryazantsev A.V., 2018. Deformations and the Sequence of the Structures Formation in the Northern Part of the Zone of Development of Maksutovo Metamorphic Complex (Southern Urals). Proceedings of Higher Educational Establishments. Geology and Exploration 1, 17-26 (in Russian) [Голионко Б.Г., Рязанцев А.В. Деформации и последовательность формирования структур северной части области развития максютовского метаморфического комплекса (Южный Урал) // Известия вузов. Геология и разведка. 2018. № 1. C. 17-26]. https://doi. org/10.32454/0016-7762-2018-1-17-26.

Golionko B.G., Ryazantsev A.V., 2020. Deformation and Mesostructural Parageneses of the Taldyk Block of the East Mugodzhar Zone (North Kazakhstan). In: Fundamental Problems of Tectonics and Geodynamics. Materials of the LII Tectonic Conference (January 28 - February 01, 2020). Vol. 1. GEOS, Moscow, p. 178-182 (in Russian) [Голионко Б.Г., Рязанцев А.В. Деформации и мезоструктурные парагенезы Талдыкского блока Восточно-Мугоджарской зоны (Северный Казахстан) // Фундаментальные проблемы тектоники и геодинамики: Материалы LII Tектонического совещания (28 января - 01 февраля 2020 г.). М.: ГEOC, 2020. T. 1. С. 178-182].

Kazakov A.P., 1976. Deformation and Superimposed Folding in Metamorphic Complexes. Nauka, Leningrad, 238 p. (in Russian) [Казаков А.П. Деформации и наложенная складчатость в метаморфических комплексах. Л.: Наука, 1976. 238 с.].

Krasnobaev A.A., Bayanova T.B., 2006. New Data on Zircon Geochronology of the Taldyk Block of Mugodzhar. In: Informational Collection of Scientific Papers of IGG UB RAS. Yearbook 2005. IGG UB RAS, Ekaterinburg, p. 297-300 (in Russian) [Краснобаев А.А., Баянова Т.Б. Новые данные по цирконовой геохронологии Талдыкского блока Мугоджар. Информационный сборник научных трудов ИГГ УрО РАН. Ежегодник-2005. Екатеринбург: ИГГ УрО РАН, 2006. С. 297-300]. 
Krasnobaev A.A., Davydov V.A., 1999. Zircon Geochronology of the Taldyk Block of Mugodzhar. Doklady Earth Sciences 366 (1), 95-99 (in Russian) [Краснобаев A.A., Давыдов В.А. Цирконовая геохронология Талдыкского блока Мугоджар // Доклады РАН. 1999. Т. 366. № 1. C. 95-99].

Lepezin G.G., Volkova N.I., Korsakov A.V., Travin A.V., Yudin D.S., 2006. Age and Thermal History of the Maksyutov Metamorphic Complex: ${ }^{40} \mathrm{Ar} /{ }^{39} \mathrm{Ar}$ Evidence. Petrology 14, 98114. https://doi.org/10.1134/S0869591106010085.

Milovsky A.V., Getling R.V., Zverev A.T., Roshkovan G.R., Sval'nova V.I., 1977. Precambrian and Lower Paleozoic of West Kazakhstan. Publishing House of Moscow State University, Moscow, 268 p. (in Russian) [Миловский А.В., Гетлинг Р.В., Зверев А.Т., Рошкован Г.Р., Свальнова В.И. Докембрий и нижний палеозой Западного Казахстана. М.: Изд-во МГУ, 1977. 268 с.].

Patalakha V.I., Slepykh Yu.F., 1974. Intersecting Folding. Nedra, Moscow, 120 p. (in Russian) [Паталаха В.И., Слепых Ю.Ф. Пересекающаяся складчатость. М.: Недра, 1974. 120 c.].

Ramsay J.G., Huber M.I., 1987. The Techniques of Modern Stucturlal Geology. Vol. 2. Folds and Fractures. Academic Press, London, New York, 700p. https://doi.org/10.1017/ S0016756800010384.

Rusin A.I., 1996. The Kitarsay Eclogite-Peridotite Association of Mugodzhar. In: Informational Collection of Scientific Papers of IGG UB RAS. Yearbook. IGG UB RAS, Ekaterinburg, p. 99-103 (in Russian) [Русин А.И. Китарсайская эклогитперидотитовая ассоциация Мугоджар // Информационный сборник научных трудов ИГГ УрО РАН. Ежегодник ИГГ УрО РАН. Екатеринбург, 1996. С. 99-103].

Rusin A.I., 2004. Metamorphic Complexes of the Urals and the Problem of Metamorphism Evolution in the Complete Cycle of Development of the Lithosphere of Mobile Belts. Brief PhD Thesis (Doctor of Geology and Mineralogy). IGG UB RAS, Ekaterinburg, 48 p. (in Russian) [Русин А.И. Метаморфические комплексы Урала и проблема эволюции метаморфизма в полном цикле развития литосферы подвижных поясов: Автореф. дис. ... докт. геол.мин. наук. Екатеринбург: ИГГ УрО РАН, 2004. 48 с.].

Ryazantsev A.V., Kuznetsov N.B., Degtyarev K.E., Romanyuk T.V., Tolmacheva T.Yu., Belousova E.A., 2019. Reconstruction of the Vendian - Cambrian Active Continental Margin of the Southern Urals: Results of Studying of Detrital Zircon from the Ordovician Terrigenous Rocks. Geotectonics
4, 43-59 (in Russian) [Рязанцев А.В., Кузнецов Н.Б., Дегтярев К.Е., Романюк Т.В., Толмачева Т.Ю., Белоусова Е.А. Реконструкция активной венд-кембрийской континентальной окраины на Южном Урале по результатам изучения детритовых цирконов из ордовикских терригенных пород // Геотектоника. 2019. № 4. С. 43-59]. https://doi.org/10.31857/S0016-853X2019343-59.

Ryazantsev A.V., Pilitsyna A.V., Golionko B.G., Artemova O.A., 2020. Early-Middle Devonian Obduction Metamorphism at the Base of the Kempirsai Ophiolite Allochthon in South Urals: U/Pb (SHRIMP) and ${ }^{39} \mathrm{Ar} /{ }^{40} \mathrm{Ar}$ Research Data. In: Fundamental Problems of Tectonics and Geodynamics. Materials of the LII Tectonic Meeting (January 28 - February 01, 2020). Vol. 2. GEOS, Moscow, p. 260-264 (in Russian) [Рязанцев А.В., Пилицына А.В., Голионко Б.Г., Артемова О.А. Раннесреднедевонский обдукционный метаморфизм в подошве Кемпирсайского офиолитового аллохтона на Южном Урале: данные U/Pb (SHRIMP) и ${ }^{39} \mathrm{Ar} /{ }^{40} \mathrm{Ar}$ исследований // Фундаментальные проблемы тектоники и геодинамики: Материалы LII Tектонического совещания (28 января - 01 февраля 2020 г.). M.: ГEOC, 2020. T. 2. C. 260-264].

State Geological Map of the USSR, 1957. Novosibirsk Islands Series. Scale 1:200000. Sheet M-40-XXX. Explanatory Note. Publishing House of the USSR Ministry of Geology, Moscow, 84 p. (in Russian) [Государственная геологическая карта СССР. Серия Новосибирские острова. Масштаб 1:200000. Лист М-40-XXX. Объяснительная записка. М.: Изд-во Мингео СССР, 1957. 84 с.].

Tevelev A.V., 2003. Middle - Late Paleozoic Development of the Ural-Kazakhstan Fold System. Brief PhD Thesis (Doctor of Geology and Mineralogy). Moscow, 48 p. (in Russian) [Тевелев А.В. Среднепозднепалеозойское развитие Урало-Казахстанской складчатой системы: Автореф. дис. ... докт. геол.-мин. наук. М., 2003. 48 с.].

Turner F.J., Weiss L.E., 1963. Structural Analysis of Metamorphic Tectonites. McGraw-Hill, New York, 545p.

Znamensky S.E., Znamenskaya N.M., 2009. The Role of Strike-Slip Duplexes in Regional Structural Control of the Late Paleozoic Gold Mineralization of Magnitogorsk Megazone (Southern Urals). Lithosphere 4, 83-92 (in Russian) [Знаменский С.Е., Знаменская Н.М. Роль сдвиговых дуплексов в региональном структурном контроле позднепалеозойского золотого оруденения Магнитогорской мегазоны (Южный Урал) // Литосфера. 2009. № 4. C. 83-92]. 